\title{
Interneuron Dysfunction in Syndromic Autism: Recent Advances
}

\author{
Tomoyuki Takano \\ Department of Pediatrics, Shiga University of Medical Science, Otsu, Japan
}

\section{Key Words}

Autism · Epilepsy $\cdot$ Interneuron $\cdot \gamma$-Aminobutyric acid

\begin{abstract}
Autism is an extremely heterogeneous disorder, but its frequent cooccurrence with epilepsy leads to speculation that there may be common mechanisms associated with these disorders. Inhibitory interneurons are considered to be the main cellular elements that control hyperexcitability in the brain, and interneuron dysfunction can cause pathological hyperexcitability linked to seizure susceptibility or epilepsy. This review summarizes some of the recent advances that support the relationship between interneuron dysfunction and cognitive impairment in human syndromic autism, with particular reference to the pathophysiological findings of murine experimental models of autism. Alterations in $\gamma$-aminobutyric acid (GABA)ergic circuits include a wide variety of neurobiological dysfunctions and do not simply involve the loss or gain of any given type of inhibitory mechanism. The characteristics of interneuron dysfunction in each murine model of autism differ for each syndrome, and these diversities may be due to differences in genetic backgrounds or some other currently unknown variances. Future studies should give us a greater understanding of the involvement of different classes of GABAergic interneurons and allow us to define the relationship between the precise pathophysiological mechanisms and the corresponding clinical phenotypes in autism.

(c) 2015 S. Karger AG, Basel
\end{abstract}

\section{Introduction}

Autism is an extremely heterogeneous disorder involving genetic, epigenetic, and environmental etiologies, though the magnitude of their roles has not yet been entirely clarified. Recent estimates suggest that approximately $10 \%$ or less of the population of persons with autism have a known cooccurring genetic syndrome [1]. The cooccurrence of epilepsy with autism has been the subject of frequent reviews $[2,3]$. This has understandably led to speculation that there may be some common mechanisms linking autism and epilepsy, suggesting the presence of an excitatory/inhibitory imbalance in the local and extended neuronal circuits in these disorders. Excitatory glutamatergic pyramidal cells specialize in transmitting information between different cortical areas and from cortical areas to other regions of the brain. During embryonic development, GABAergic neuroblasts from the ganglionic eminences migrate dorsally to populate the cortex, as well as to all other structures within the telencephalon, such as the hippocampus, the striatum, and the amygdala [4]. These inhibitory GABAergic interneurons primarily contribute to local neural assemblies where they provide inhibitory inputs and shape synchronized oscillations [5]. The balance between excitation and inhibition is crucial for cortical function [6], and consequently important developmental and physiological mechanisms have evolved to maintain this dynamic equilibrium [7]. Inhibitory interneurons are considered to be

\section{KARGER 125}

C 2015 S. Karger AG, Basel

0378-5866/15/0376-0467\$39.50/0
Dr. Tomoyuki Takano, MD, $\mathrm{PhD}$

Department of Pediatrics

Shiga University of Medical Science

Seta-Tsukinowa, Otsu 520-2192 (Japan)

www.karger.com/dne
E-Mail tmyktkn@ belle.shiga-med.ac.jp 
Table 1. Syndromic autism and the pathological mechanisms of inhibitory dysfunction

\begin{tabular}{|c|c|c|c|c|c|}
\hline Syndrome & Neurological symptoms & Genes & Gene functions & Inhibitory dysfunction in mouse models & Ref. \\
\hline Fragile X & $\begin{array}{l}\text { Social anxiety, extreme } \\
\text { shyness, gaze avoidance }\end{array}$ & $F M R 1$ & $\begin{array}{l}\text { Transport of } \\
\text { mRNA, regulation } \\
\text { of protein } \\
\text { translation in } \\
\text { neuronal dendrites }\end{array}$ & $\begin{array}{l}\text { Cx, Hp: GABA receptor expression } \downarrow \text {, fast } \\
\text { spiking interneurons } \downarrow \text {, low threshold } \\
\text { spiking interneurons } \downarrow \\
\text { Am: inhibitory postsynaptic currents } \downarrow \text {, } \\
\text { inhibitory synapses } \downarrow\end{array}$ & $\begin{array}{l}20-22 \\
27,28\end{array}$ \\
\hline Rett & $\begin{array}{l}\text { Intellectual disability, } \\
\text { psychomotor impairment, } \\
\text { autistic behavior }\end{array}$ & MECP2 & $\begin{array}{l}\text { Transcription } \\
\text { repressor, } \\
\text { regulation of } \\
\text { chromatin } \\
\text { remodeling and } \\
\text { gene expression }\end{array}$ & $\begin{array}{l}\text { Cx: parvalbumin-expressing interneu- } \\
\text { rons } \uparrow, \text { GABAergic presynaptic function } \downarrow \text {, } \\
\text { soma size of interneurons (calretinin-, } \\
\text { parvalbumin-, and somatostatin-positive } \\
\text { cells) } \downarrow \text {, GABAergic structural plasticity } \downarrow\end{array}$ & $\begin{array}{l}35,37- \\
39\end{array}$ \\
\hline Angelman & $\begin{array}{l}\text { Mental retardation, absent } \\
\text { speech, autistic behavior, } \\
\text { inappropriate happy } \\
\text { demeanor, learning and } \\
\text { memory impairment, gate } \\
\text { ataxia, epilepsy }\end{array}$ & $U B E 3 A$ & $\begin{array}{l}\text { Regulation of } \\
\text { synaptic function, } \\
\text { transcriptional } \\
\text { coactivator for } \\
\text { steroid hormone } \\
\text { receptors }\end{array}$ & $\begin{array}{l}\text { Cx: inhibitory synaptic drive onto } \\
\text { pyramidal neurons } \downarrow \text {, inhibitory } \\
\text { presynaptic vesicle cycling } \downarrow \\
\text { Hp, Am: parvalbumin-positive } \\
\text { interneurons } \downarrow\end{array}$ & $\begin{array}{l}47,49 \\
50\end{array}$ \\
\hline NF1 & $\begin{array}{l}\text { Learning disability, verbal } \\
\text { and nonverbal disabilities, } \\
\text { attention deficit disorder, } \\
\text { mental retardation, } \\
\text { seizures }\end{array}$ & NF1 & $\begin{array}{l}\text { Regulation of RAS } \\
\text { activity, } \\
\text { modulation of } \\
\text { RAS/ERK signaling }\end{array}$ & $\begin{array}{l}\text { Hp: GABA-mediated inhibition } \uparrow \\
\mathrm{Cx}, \mathrm{Hp}, \mathrm{CPu}: \mathrm{GABA} \text { release } \uparrow\end{array}$ & $60-62$ \\
\hline TSC & $\begin{array}{l}\text { Epilepsy, cognitive } \\
\text { impairment, learning } \\
\text { disabilities, mental } \\
\text { retardation, autism, } \\
\text { attention deficit, and } \\
\text { hyperactivity }\end{array}$ & $\begin{array}{l}\text { TSC1, } \\
\text { TSC2 }\end{array}$ & $\begin{array}{l}\text { Inhibition of } \\
\text { mTORC1 }\end{array}$ & $\begin{array}{l}\text { Cx, Hp: mTORC } 1 \text { signaling in GABAergic } \\
\text { interneurons } \uparrow, \text { numbers of GABAergic } \\
\text { cells } \downarrow \\
\text { Hp: amplitude of spontaneous miniature } \\
\text { inhibitory currents } \downarrow \text {, evoked inhibitory } \\
\text { currents } \downarrow \text {, synaptic inhibitory potentials } \downarrow \\
\text { Ce: Purkinje cell degeneration } \uparrow, \text { Purkinje } \\
\text { cell excitability } \downarrow\end{array}$ & $\begin{array}{l}70,72 \\
79,80\end{array}$ \\
\hline
\end{tabular}

$\mathrm{Cx}=$ Cerebral cortex; $\mathrm{Hp}=$ hippocampus; $\mathrm{Am}=$ amygdala; $\mathrm{Ce}=$ cerebellum; $\mathrm{CPu}=$ striatum; $\uparrow=$ increased numbers or upregulation; $\downarrow$ = decreased numbers or downregulation.

the main cellular elements that control hyperexcitability in the brain [8], and interneuron dysfunction can cause pathological hyperexcitability linked to seizure susceptibility or epilepsy $[9,10]$. However, in neurodevelopmental disorders such as autism, it is not well understood how specific interneuron dysfunction may contribute to the pathophysiology of cognitive impairment. The purpose of this review is to critically summarize recent advances that support the relationship between interneuron dysfunction and cognitive impairment in human syndromic autism. Autism is so heterogeneous a disorder that this review has concentrated on defined syndromes with known genetic defects, including fragile X syndrome, Rett syndrome, Angelman syndrome, neurofibromatosis type
1 (NF1), and tuberous sclerosis complex (TSC), with particular reference to the pathophysiological findings of murine experimental models of autism (table 1).

\section{Fragile X Syndrome}

Fragile $\mathrm{X}$ syndrome is one of the most well-known diseases caused by a chromosomal mutation leading to mental retardation. Between 21 and $50 \%$ of boys with fragile X syndrome are on the autistic spectrum [11], and $1-6 \%$ of the autism population has fragile $\mathrm{X}$ syndrome [12]. A milder presentation of autistic symptoms is more common, and the most frequent symptoms tend 
to be social anxiety, extreme shyness, and gaze avoidance [13]. Fragile X syndrome is attributed to transcriptional silencing of the fragile $\mathrm{X}$ mental retardation 1 (FMR1) gene and the consequent loss of the gene product of $F M R 1$, i.e. fragile $\mathrm{X}$ mental retardation protein (FMRP) [14]. In humans, the silencing of FMR1 is caused by hypermethylation, which occurs when a trinucleotide (CGG) repeat located in the $5^{\prime}$ untranslated region of the gene expands to a length of more than 200 repeats. FMRP acts as a translational repressor of specific mRNA at synapses and associates not only with these target mRNA but also with the dendritic, nontranslatable RNA $B C 1$ (a short nontranslatable RNA polymerase III transcript). When FMRP is not present, the loss of translational repression of specific mRNA at synapses could result in the synaptic dysfunction phenotype of fragile X syndrome [15]. This FMRP dysfunction perhaps explains the paucity of mature dendrites seen in an autopsy series of fragile $\mathrm{X}$ syndrome [16]. These changes are observed in both excitatory and inhibitory neurotransmission across multiple brain regions, including the amygdala, the cerebral cortex, the hippocampus, and the striatum $[17,18]$.

In studies of Fmrl knockout mouse models of fragile $\mathrm{X}$ syndrome, the overactivation of metabotropic glutamate receptor signaling has been reported to be a primary defect in the cerebral cortex and hippocampus [19]. A number of studies have also implicated alterations in the GABA system, including the dramatic decreased expression of GABA receptors [20]. Electrophysiological studies have shown that the local excitation of fast-spiking inhibitory interneurons (perisomatic targeting interneurons) decreases in the neocortex, which could explain the decrease in synchrony in the gamma frequency of the neuronal network [21]. The activation of low-threshold spiking interneurons (dendritic-targeting interneurons), which contribute to the synchronization of neuronal networks over a wide range of frequencies, has also been reported to decrease [22]. This alteration results in a reduced inhibitory output, which in turn alters the synchronization and spike output of excitatory neuronal networks in the neocortex. These investigations indicate that a dysfunction in the inhibitory microcircuit plays a key role in the hyperexcitable neural network in fragile X syndrome. Thus, the cortical networks in fragile X syndrome are hyperexcitable and highly synchronous, which explains the state-dependent network defects related to intellectual disability, the increased incidence of seizures, and sensory integration dysfunctions associated with this syndrome $[23,24]$.

Interneuron Dysfunction in Syndromic Autism
The amygdala is a central processing center for information with emotional and social relevance. The amygdala dysfunction in fragile $\mathrm{X}$ syndrome is supported by structural and functional MRI studies as well as animal behavioral studies [25]. Fmr1 knockout mice exhibit abnormal social behavior [26], consistent with the findings observed in humans [23]. In the amygdala of Fmr1 knockout mice, a dramatic reduction in the frequency and amplitude of the phasic inhibitory postsynaptic currents, as well as in the number of inhibitory synapses, was observed [27]. This experiment revealed a significant neuronal hyperexcitability in the principal neurons of the amygdala in Fmrl knockout mice, which was strikingly successfully treated by pharmacological augmentation of the tonic inhibitory tone using the GABA agonist gaboxadol. Using a combination of electrophysiological and genetic approaches, the development of both presynaptic and postsynaptic components of inhibitory neurotransmission in the FXS amygdala is also dramatically altered during critical stages of neuronal circuit formation [28]. These investigations provide important evidence for the development of therapeutic strategies for the treatment of amygdala-based symptoms in fragile X syndrome.

\section{Rett Syndrome}

Rett syndrome is a complex and severe $\mathrm{X}$-linked progressive neurological disorder leading to intellectual disability, psychomotor impairment, and autistic behavior that primarily manifests in girls during childhood after an apparently normal early development [29]. More than 95\% of Rett syndrome cases are associated with mutations in the genes encoding a transcription repressor, i.e. methyl-CpG-binding protein 2 (MeCP2), which binds methylated DNA and regulates chromatin remodeling and gene expression [30]. MeCP2 is found in a wide variety of tissues, but it appears to be most abundant in the brain [31]. During embryogenesis, the neuronal $\mathrm{MeCP} 2$ level is relatively low; however, it progressively increases during the postnatal period, thus suggesting that $\mathrm{MeCP} 2$ plays a pivotal role in neuronal maturation throughout the central nervous system [32].

Mecp2-null mutant mice appear developmentally normal up to 6 weeks after birth; however, after this period, the mice develop neurologic symptoms, including tremors, motor impairment, hypoactivity, seizures, kyphosis, and the classic forearm movements associated with human Rett syndrome [31]. Studies in Mecp2 knockout mice have indicated that the lack of Mecp2 induces a shift 
in homeostatic balance between excitation and inhibition in favor of inhibition. For instance, Mecp2 knockout neurons have lower excitatory postsynaptic currents (EPSC) both in culture and in murine models [33]. Whole-cell patch clamp recordings of layer $\mathrm{V}$ pyramidal neurons in the primary somatosensory cortex reveal a reduction of both spontaneous EPSC and spontaneous action potential firing [34]. Stronger innervation of the pyramidal neurons by parvalbumin-expressing GABAergic interneurons causes a reduction in the network activity in the visual cortex [35]. These imbalances in favor of inhibition may be responsible for the functional hypoactivity in the cerebral cortex and resultant cognitive and motor dysfunctions observed in Rett syndrome. Contrary to the neocortical circuit, hippocampal hyperactivity and the high frequency of spontaneous multiunit spikes in CA3 are observed, suggesting an impaired excitation/inhibition balance in the CA3 pyramidal neurons, thus leading to a hyperactive hippocampal network [36]. These hippocampal hyperactivities are suggested to contribute to the limbic seizures seen in patients with Rett syndrome.

Recent studies on Mecp2 mutant mice have reported developmental alterations specific to GABAergic interneurons. GABAergic interneurons contain significantly higher levels of MeCP2 protein as compared to nonGABAergic cells [37]. MeCP2-deficient GABAergic neurons show significant deficits in their presynaptic function and GABA immunoreactivity [37]. These results highlight the critical role of Mecp2 in GABA synthesis in GABA-releasing neurons. Mecp2 deletion also results in a reduction in the soma size of 3 major classes of cortical interneurons (i.e. calretinin-, parvalbumin-, and somatostatin-positive cells) and induces an imbalance of the density of the distribution of these interneurons [38]. The loss of the Mecp2 function strongly interferes with the correct establishment of the neocortical inhibitory system, producing effects that are specific to different interneuron subtypes [38]. A role for $M E C P 2$ in inhibitory cell function is also indicated by the observation that Mecp2 mutants reared in an enriched environment do not show an environmental enrichment-induced reduction of the inhibitory synaptic density in the cortex typical of wildtype mice [39]. In contrast, the lack of Mecp2 did not prevent the environmental enrichment effects on the excitatory synaptic contacts. These results indicate that $M E C P 2$ is required for the structural plasticity of cortical GABAergic interneurons. On the other hand, nonhuman primates provide powerful experimental models to study human development and disease because of their genetic and physiological similarities to humans. Recent advanc- es in gene editing technology have led to the successful generation of a transgenic monkey model of Rett syndrome by TALEN-mediated mutagenesis of MECP2 [40].

\section{Prader-Willi Syndrome and Angelman Syndrome}

Prader-Willi syndrome and Angelman syndrome are the prototypical disorders of aberrations of imprinted genes [41]. Approximately $70-75 \%$ of individuals with Prader-Willi syndrome have a deletion of the paternally contributed 15q11.2q13.1 region, while in Angelman syndrome $70 \%$ of the affected individuals have a deletion of the maternally contributed region. Most patients with Prader-Willi syndrome who do not have the 15q11.2q13.1 deletions have uniparental disomy for chromosome 15 with 2 maternal copies and no paternal copies. Paternal uniparental disomy accounts for a low percentage of Angelman syndrome cases. Mutations in the ubiquitin protein ligase E3A (UBE3A) gene, located at 15q11.2, have also been found in some patients with Angelman syndrome [42]. This gene is imprinted in the brain [43] and it is the gene responsible for the Angelman syndrome phenotype. Prader-Willi syndrome is characterized by hypotonia and feeding difficulties in early life, hyperphagia and obesity later, a short stature, hypogonadism, and acromicria. Behavioral problems are common and psychomotor development is mildly affected. Angelman syndrome is characterized by severe mental retardation, absent speech, autistic behavior, an inappropriate happy demeanor, gate ataxia, epilepsy, and dysmorphic features.

$U B E 3 A$ encodes an E3 ubiquitin ligase that, in the brain, is expressed primarily from the maternal allele as a result of neuron-specific imprinting [43]. Ube $3 a$ has been demonstrated to play a crucial role in regulation of synaptic function. The loss of Ube3a function in an Angelman syndrome murine model leads to a defect in experience-dependent synaptic plasticity $[44,45]$, which is closely associated with many features of Angelman syndrome, including learning and memory impairment and motor dysfunction [46]. The loss of maternally inherited Ube $3 a$ results in a decreased excitatory synaptic drive onto neocortical pyramidal neurons, which appears to be at odds with the enhanced seizure susceptibility; however, the inhibitory drive onto the pyramidal neurons is even more severely decreased. This inhibitory deficit follows the loss of excitatory inputs and appears to arise from defective presynaptic vesicle cycling in multiple interneuron populations [47]. These investigations indicate that Ube $3 a$ loss results in more severe inhibitory deficits at the 
cellular and circuit levels and may contribute to the seizure susceptibility in Angelman syndrome. Ube3a also acts as a transcriptional coactivator for steroid hormone receptors [48]. Defective glucocorticoid receptor signaling in Ube3a knockout mice could lead to the downregulation of parvalbumin-positive interneurons in the hippocampus and the basolateral amygdala from the early postnatal period [49]. This finding is closely associated with the emergence of anxiety and other behavioral deficits in Angelman syndrome, because parvalbumin-positive interneurons are essential for hippocampal longterm potentiation and contextual fear conditioning [50].

\section{Neurofibromatosis Type 1}

NF1 is transmitted as an autosomal dominant trait and it is notable for its great variability of expression. Approximately $50 \%$ of such patients have a learning disability, with no specific pattern unique to those with NF1 [51]. Both verbal and nonverbal disabilities occur, as well as attention deficit disorder [52]. Fewer than 10\% have mental retardation [53], and seizures occur in approximately $6-10 \%$ of all such patients [54]. The NF1 (neurofibromin 1) gene is located at $17 q 11.2$ and encodes neurofibromin, which is expressed in multiple cell types but is highly expressed in Schwann cells, oligodendrocytes, and neurons [55]. Neurofibromin includes a functional GTPase-activating protein (GAP) domain that regulates the conversion of Ras-guanosine triphosphate (GTP) to Ras-guanosine diphosphate (GDP) [56]. Ras is a membrane-bound intracellular signaling molecule that is activated by complexing with GTP upon ligand binding to a membrane receptor tyrosine kinase. GAP regulates this process by stimulating the GTPase activity that is intrinsic to Ras [57].

An important function of neurofibromin is regulation of the activity of the oncogene RAS. Neurofibromin is also thought to modulate Ras/extracellular signal-regulated kinase (ERK) signaling, long-term potentiation (LTP), and learning in mice [58]. LTP is a stable, long-lasting change in synaptic strength widely believed to be a key cellular mechanism for learning and memory that is dependent on Ras function [59]. It has been shown that the learning deficits of mice carrying a heterozygous null mutation of $\mathrm{Nf1}$ can be rescued by genetic and pharmacological manipulations which decrease Ras function. In addition, this murine model has increased GABA-mediated inhibition and specific deficits in LTP, both of which can be reversed by decreasing Ras function [58]. These

Interneuron Dysfunction in Syndromic Autism investigations indicate that the learning deficits associated with NF1 may be caused by excessive Ras activity, which leads to impairments in LTP caused by increased GABA-mediated inhibition.

The overactive ERK signaling in hippocampal interneurons causes excessive GABA release, which is associated with memory impairment [60]. Neurofibromin modulates ERK/synapsin1-dependent GABA release, which in turn modulates hippocampal LTP and learning, which can be reversed by pharmacological downregulation of ERK signaling [61]. Ras-dependent increases in GABA release are also found in the medial prefrontal cortex and striatum in Nf1 heterozygous null mutants, suggesting that neurofibromin is an important molecular regulator of the interneuron activity in the prefrontal cortex and striatum, brain regions that are critical for working memory performance [62]. These reports demonstrate that the excess GABA release in multiple brain regions is closely associated with reduced synaptic strengthening and the resultant learning deficits or working memory impairment in NF1.

\section{Tuberous Sclerosis Complex}

TSC is a disorder of autosomal dominant inheritance that affects multiple organ systems, resulting in manifold clinical expressions. TSC is caused by heterozygous lossof-function mutations of either the TSC1 or the TSC2 gene, which encode the protein hamartin or tuberin, respectively. Hamartin and tuberin form a complex that inhibits the mammalian target of rapamycin complex 1 (mTORC1), a kinase that controls translation and cell growth [63]. The mTORC1 kinase is inhibited by the GTPase-activating domain of tuberin on the Ras-like protein Rheb [64]. Therefore, the loss of function of TSC1 or TSC2 leads to the increased activity of mTORC1 [65]. The mTOR kinase complex is the central component of a cell growth pathway that responds to changes in nutrients, energy balance, and extracellular signals to control cellular processes [66]. Epilepsy is the most common presenting symptom in TSC. TSC is also associated with a wide range of cognitive and behavioral manifestations. Approximately $50 \%$ of all individuals with TSC have a normal intelligence, whereas the other half all have some degree of cognitive impairment ranging from mild learning disabilities to severe mental retardation. Autistic spectrum disorders affect up to $50 \%$ of individuals with TSC [67], and attention-deficit/hyperactivity and related disorders also are common, affecting approximately $50 \%$ 
Fig. 1. Illustrative summary of the inhibitory dysfunction in multiple brain regions in 5 genetic syndromes associated with autism. Fragile X syndrome, Angelman syndrome, and TSC revealed mainly downregulation of inhibitory neuronal function; however, NF1 showed primarily upregulation in the GABA-mediated inhibitory system. In Rett syndrome, GABAergic presynaptic function is mainly downregulated; however, a stronger innervation of the pyramidal neurons by parvalbumin-expressing interneurons has also been reported, suggesting the presence of both dysregulation mechanisms in inhibitory function.

\begin{tabular}{|l|l|l|l|l|l|}
\hline Syndrome & Cerebral cortex & Hippocampus & Amygdala & Striatum & Cerebellum \\
\hline Fragile X & & & & & \\
\hline Rett & & & & & \\
\hline Angelman & & & & & \\
\hline NF1 & & & & & \\
\hline TSC & & & & & \\
\hline
\end{tabular}

of patients [68]. The high incidence of both epilepsy and autism in patients with TSC and the dramatic response of infantile spasms to a GABA-potentiating agent, i.e. vigabatrin, lead to the hypothesis that patients with TSC have an altered GABAergic interneuron function.

Murine models of TSC exhibit behavioral changes that parallel the human disease phenotypes including seizures, decreased social interaction, altered vocalizations, and deficits in learning and memory [69]. In conditional knockout mice with selective deletion of the Tsc1 gene in GABAergic interneuron progenitor cells, cortical and hippocampal GABAergic interneurons show increased mTORC1 signaling. The total numbers of GABAergic cells are reduced in the cortex, and ectopic clusters of cells with increased mTORC1 signaling are also seen. These findings support the hypothesis that the Tsc1 gene is involved in GABAergic interneuron development, suggesting that inhibitory cortical neurons may contribute to the pathogenesis of epilepsy and possibly autism in patients with TSC [70]. The hippocampus is a region of the brain important for learning and memory that can be involved in the generation of temporal lobe seizures [71]. The genetic deletion of $T s c 1$ in murine hippocampal neurons results in a deficit in inhibitory synaptic function manifested by the decreased amplitude of spontaneous miniature inhibitory currents, reduced evoked inhibitory currents, and reduced synaptic inhibitory potentials. These findings likely result from a primary imbalance of excita- tion and inhibition due to the reduced inhibition on Tsc1 knockout pyramidal neurons [72]. Thus, the excitation/ inhibition imbalance resulting from dysregulated TSC/ mTOR signaling may contribute to neurological dysfunction, including epilepsy and autistic disorders in TSC.

The neurological basis of autism has been thought to lie in multiple noncortical/subcortical regions in addition to the cortex; however, recent evidence suggests that the cerebellum may also be an important determinant in autism [73]. The cerebellum is well known to coordinate motor function; however, it also plays important roles in higher-order cognitive functions [74]. The cerebellum communicates with the cerebral cortex via the inhibitory GABAergic axons of Purkinje cells that project to the deep cerebellar nuclei [75]. The deep cerebellar nuclei then send projections to the thalamus and cerebral cortex [76]. In autism patients, the cerebellar abnormalities observed by brain MRI or autopsy studies include Purkinje cell loss, general cerebellar hypoplasia, vermal hypoplasia or hyperplasia, reduced gray matter, and GABAergic neuronal dysfunction $[77,78]$. The murine TSC model with Purkinje cell-specific Tsc2 loss exhibits progressive Purkinje cell degeneration and autistic-like deficits, and behavioral deficits are prevented with an mTOR inhibitor, i.e. rapamycin [79]. This study suggests that Purkinje cells play an important role in TSC-associated autism and provides a murine model of a $T s c 2$ mutation in which to study the relationship between the cerebellum and au- 
tism. Both heterozygous and homozygous loss of Tsc1 in murine cerebellar Purkinje cells also results in autisticlike behaviors, including abnormal social interaction, repetitive behavior, and vocalizations, in addition to decreased Purkinje cell excitability. The pathological and behavioral deficits are also prevented by rapamycin treatment. These studies demonstrate the novel role of TSC in Purkinje cell function and define a molecular basis for a cerebellar contribution to cognitive disorders, such as autism [80].

\section{Conclusions and Perspectives}

Alterations to GABAergic circuits during the development of syndromic autism include a wide variety of neurobiological dysfunctions and do not simply involve the loss or gain of a given type of inhibitory mechanism. The characteristics of interneuron dysfunction in each murine model of autism differ for each syndrome (fig. 1), and these diversities may be due to differences in genetic backgrounds or other currently unknown variances. Epilepsy and autism exhibit a similar neurobiological dys- function, inducing an excitatory/inhibitory imbalance, and interneurons play a crucial role at the crossroads of these disorders. Future studies should give us a greater understanding of the involvement of different classes of GABAergic interneurons in the relationship between the precise pathophysiological mechanisms and corresponding clinical phenotypes in autism. The identification of susceptibility genes is becoming easier as a result of recent developments in molecular genetics. Further comprehensive research into the molecular mechanisms of interneuron dysfunction in autism is necessary to aid in the development of disease-specific targeted therapies as well as epilepsy treatment.

\section{Acknowledgement}

This work was supported by a KAKENHI Grant-in-Aid for Scientific Research (C; No. 15K09617).

\section{Disclosure Statement}

The author has no conflicts of interest to disclose.

\section{References}

$>1$ Dykens EM, Lense M: Intellectual disabilities and autism spectrum disorder: a cautionary note: in Amaral DG, Dawson G, Geschwind DH (eds): Autism Spectrum Disorders. New York, Oxford University Press, 2011, pp 263269.

-2 Brooks-Kayal A: Epilepsy and autism spectrum disorders: are there common developmental mechanisms? Brain Dev 2010;32:731738.

>3 Tuchman R, Alessandri M, Cuccaro M: Autism spectrum disorders and epilepsy: moving towards a comprehensive approach to treatment. Brain Dev 2010;32:719-730.

4 Kepecs A, Fishell G: Interneuron cell types are fit to function. Nature 2014;505:318-326.

$>5$ Klausberger T, Somogyi P: Neuronal diversity and temporal dynamics: the unity of hippocampal circuit operations. Science 2008;321: 53-57.

6 Yizhar O, Fenno LE, Prigge M, Schneider F, Davidson TJ, O'Shea DJ, Sohal VS, Goshen I, Finkelstein J, Paz JT, Stehfest K, Fudim R, Ramakrishnan C, Huguenard JR, Hegemann P, Deisseroth K: Neocortical excitation/inhibition balance in information processing and social dysfunction. Nature 2011;477:171-178.
7 Haider B, Duque A, Hasenstaub AR, McCormic DA: Neocortical network activity in vivo is generated through a dynamic balance of excitation and inhibition. J Neurosci 2006;26: 4535-4545.

8 Dichter MA, Ayala GF: Cellular mechanisms of epilepsy: a status report. Science 1987;237: 157-164.

$\checkmark 9$ Takano T: Seizure susceptibility in polymicrogyria: clinical and experimental approaches. Epilepsy Res 2011;96:1-10.

10 Takano T, Matsui K: Increased expression of GAP43 in interneurons in a rat model of experimental polymicrogyria. J Child Neurol 2014;30:716-728.

11 Moss J, Howlin P: Autism spectrum disorders in genetic syndromes: implications for diagnosis, intervention and understanding the wider autism spectrum disorder population. J Intellect Disabil Res 2009;53:852-873.

12 Fombonne E, Du Mazaubrun C, Cans C, Grandjean H: Autism and associated medical disorders in a French epidemiological survey. J Am Acad Child Adolesc Psychiatry 1997;36: 1561-1569.

13 Roberts JE, Weisenfeld LAH, Hatton DD, Heath M, Kaufmann WE: Social approach and autistic behavior in children with fragile X syndrome. J Autism Dev Disord 2007;37: 1748-1760.
14 Penagarikano O, Mulle JG, Warren ST: The pathophysiology of fragile X syndrome. Annu Rev Genomics Hum Genet 2007;8:109-129.

15 Zalfa F, Giorgi M, Primerano B, Moro A, Di Penta A, Reis S, Oostra B, Bagni C: The fragile $\mathrm{X}$ syndrome protein FMRP associates with BC1 RNA and regulates the translation of specific mRNAs at synapses. Cell 2003;112:317-327.

16 Greenough WT, Klintsova AY, Irwin SA, Galvez R, Bates KE, Weiler IJ: Synaptic regulation of protein synthesis and the fragile $\mathrm{X}$ protein. Proc Natl Acad Sci USA 2001;98: 7101-7106

17 Cea-Del Rio CA, Huntsman MM: The contribution of inhibitory interneurons to circuit dysfunction in fragile X syndrome. Front Cell Neurosci 2014;8:1-8.

18 Paluszkiewicz SM, Martin BS, Huntsman MM: Fragile X syndrome: the GABAergic system and circuit dysfuntion. Dev Neurosci 2011;33:349-364.

19 Dolen G, Bear MF: Role for metabotropic glutamate receptor 5 (mGluR5) in the pathogenesis of fragile $\mathrm{X}$ syndrome. J Neurophysiol 2007;586:1503-1508.

20 D'Hulst C, De Geest N, Reeve SP, Van Dam D, De Deyn PP, Hassan BA, Kooy RF: Decreased expression of the GABAa receptor in fragile X syndrome. Brain Res 2006;1121: 238-245.
Interneuron Dysfunction in Syndromic Autism
Dev Neurosci 2015;37:467-475 DOI: $10.1159 / 000434638$ 
-21 Klausberger T, Magill PJ, Márton LF, Roberts JD, Cobden PM, Buzsáki G, Somogyi P: Brain-state and cell-type-specific firing of hippocampal interneurons in vivo. Nature 2003;421:844-848.

-22 Paluszkiewicz SM, Olmos-Serrano JL, Corbin JG, Huntsman MM: Impaired inhibitory control of cortical synchronization in fragile X syndrome. J Neurophysiol 2011;106:2264-2272.

-23 Hagerman RJ, Berry-Kravis E, Kaufmann WE, Ono MY, Tartaglia N, Lachiewicz A, Kronk R, Delahunty C, Hessl D, Visootsak J, Picker J, Gane L, Tranfaglia M: Advances in the treatment of fragile $\mathrm{X}$ syndrome. Pediatrics 2009;123:378-390.

24 Hagerman PJ, Stafstrom CE: Origins of epilepsy in fragile X syndrome. Epilepsy Curr 2009;9:108-112.

25 Gothelf D, Furfaro JA, Hoeft F, Eckert MA, Hall SS, O'Hara R, Erba HW, Ringel J, Hayashi KM, Patnaik S, Golianu B, Kraemer HC, Thompson PM, Piven J, Reiss AL: Neuroanatomy of fragile $\mathrm{X}$ syndrome is associated with aberrant behavior and the fragile $\mathrm{X}$ mental retardation protein (FMRP). Ann Neurol 2008; 63:40-51.

-26 McNaughton CH, Moon J, Strawderman MS, Maclean KN, Evans J, Strupp BJ: Evidence for social anxiety and impaired social cognition in a mouse model of fragile $\mathrm{X}$ syndrome. Behav Neurosci 2008;122:293-300.

-27 Olmos-Serrano JL, Paluszkiewicz SM, Martin BS, Kaufmann WE, Corbin JG, Huntsman MM: Defective GABAergic neurotransmission and pharmacological rescue of neuronal hyperexcitability in the amygdala in a mouse model of fragile X syndrome. J Neurosci 2010; 30:9929-9938.

-28 Vislay RL, Martin BS, Olmos-Serrano JL, Kratovac S, Nelson DL, Corbin JG, Huntsman MM: Homeostatic responses fail to correct defective amygdala inhibitory circuit maturation in fragile X syndrome. J Neurosci 2013; 33:7548-7558.

29 Hagberg B, Aicardi J, Dias K, Ramos O: A progressive syndrome of autism, dementia, ataxia, and loss of purposeful hand use in girls: Rett's syndrome - report of 35 cases. Ann Neurol 1983;14:471-479.

-30 Shin J, Ming GL, Song H: By hook or by crook: multi-faceted DNA-binding properties of MeCP2. Cell 2013;152:940-942.

-31 Shahbazian M, Young J, Yuva-Paylor L, Spencer C, Antalffy B, Noebels J, Armstrong D, Paylor R, Zoghbi H: Mice with truncated $\mathrm{MeCP} 2$ recapitulate many Rett syndrome features and display hyperacetylation of histone H3. Neuron 2002;35:243-254.

- 32 Skene PJ, Illingworth RS, Webb S, Kerr AR, James KD, Turner DJ, Andrews R, Bird AP: Neuronal MeCP2 is expressed at near histone-octamer levels and globally alters the chromatin state. Mol Cell 2010;37:457-468.

33 Chao HT, Zoghbi HY, Rosenmund C: MeCP2 controls excitatory synaptic strength by regulating glutamatergic synapse number. Neuron 2007;56:58-65.
4 Tropea D, Giacometti E, Wilson NR, Beard C, McCurry C, Fu DD, Flannery R, Jaenisch R, Sur M: Partial reversal of Rett syndrome-like symptoms in $\mathrm{MeCP} 2$ mutant mice. Proc Natl Acad Sci USA 2009;106:2029-2034.

- 35 Durand S, Patrizi A, Quast KB, Hachigian L, Pavlyuk R, Saxena A, Carninci P, Hensch TK, Fagiolini M: NMDA receptor regulation prevents regression of visual cortical function in the absence of Mecp2. Neuron 2012;76:10781090.

36 Calfa G, Li W, Rutherford JM, Pozzo-Miller L: Exitation/inhibition imbalance and impaired synaptic inhibition in hippocampal area CA3 of Mecp2 knockout mice. Hippocampus 2015;25:159-168.

37 Chao HT, Chen H, Samaco RC, Xue M, Chahrour M, Yoo J, Neul JL, Gong S, Lu HC, Heintz N, Ekker M, Rubenstein JL, Noebels JL, Rosenmund C, Zoghbi HY: Dysfunction in GABA signaling mediates autism-like stereotypies and Rett syndrome phenotypes. Nature 2010;468:263-269.

38 Tomassy GS, Morello N, Calcagno E, Giustetto $\mathrm{M}$ : Developmental abnormalities of cortical interneurons precede symptoms onset in a mouse model of Rett syndrome. J Neurochem 2014;131:115-127.

39 Lonetti G, Angelucci A, Morando L, Boggio EM, Giustetto M, Pizzorusso T: Early environmental enrichment moderates the behavioral and synaptic phenotype of MeCP2 null mice. Biol Psychiatry 2010;67:657-665.

40 Liu H, Chen Y, Niu Y, Zhang K, Kang Y, Ge W, Liu X, Zhao E, Wang C, Lin S, Jing B, Si C, Lin Q, Chen X, Lin H, Pu X, Wang Y, Qin B, Wang F, Wang H, Si W, Zhou J, Tan T, Li T, Ji S, Xue Z, Luo Y, Cheng L, Zhou Q, Li S, Sun YE, Ji W: TALEN-mediated gene mutagenesis in rhesus and cynomolgus monkeys. Cell Stem Cell 2014;14:323-328.

- 41 Gurrieri F, Accadia M: Genetic imprinting: the paradigm of Prader-Willi and Angelman syndromes. Endocr Dev 2009;14:20-28.

42 Kishino T, Lalande M, Wagstaff J: UBE3A/ E6-AP mutations cause Angelman syndrome. Nat Genet 1997;15:70-73.

43 Albrecht U, Sutcliffe JS, Cattannach BM, Beechey CV, Armstrong D, Eichele G, Beaudet AL: Imprinted expression of the murine Angelman syndrome gene, Ube3a, in hippocampal and Purkinje neurons. Nat Genet 1997; 17:75-78.

- 44 Greer PL, Hanayama R, Bloodgood BL, Mardinly AR, Lipton DM, Flavell SW, Kim TK, Griffith EC, Waldon Z, Maehr R, Ploegh HL, Chowdhury S, Worley PF, Steen J, Greenberg ME: The Angelman syndrome protein Ube3A regulates synapse development by ubiquitinating arc. Cell 2010;140:704-716.

45 Jana NR: Understanding the pathogenesis of Angelman syndrome through animal models. Neural Plast 2012;710943.
46 Heck DH, Zhao Y, Roy S, LeDoux MS, Reiter LT: Analysis of cerebellar function in Ube3adeficient mice reveals novel genotype-specific behaviors. Hum Mol Genet 2008;17:21812189.

47 Wallace ML, Burette AC, Weinberg RJ, Philpot BD: Maternal loss of Ube3a produces an excitatory/inhibitory imbalance through neuron type-specific synaptic defects. Neuron 2012;74:793-800.

48 Nawaz Z, Lonard DM, Smith CL, Lev-Lehman E, Tsai SY, Tsai MJ, O'Malley BW: The Angelman syndrome associated-protein, E6$\mathrm{AP}$, is a coactivator for the nuclear hormone receptor superfamily. Mol Cell Biol 1999;19: 1182-1189.

49 Godavarthi SK, Sharma A, Jana NR: Reversal of reduced parvalbumin neurons in hippocampus and amygdala of Angelman syndrome model mice by chronic treatment of fluoxetine. J Neurochem 2014;130:444-454.

50 Chen YJ, Zhang M, Yin DM, Wen L, Ting A, Wang P, Lu YS, Zhu XH, Li SJ, Wu CY, Wang XM, Lai C, Xiong WC, Mei L, Gao TM: ErbB4 in parvalbumin-positive interneurons is critical for neuregulin 1 regulation of long-term potentiation. Proc Natl Acad Sci USA 2010; 107:21818-21823.

51 Hyman SL, Shores EA, North KN: Learning disabilities in children with neurofibromatosis type 1: subtypes, cognitive profile, and attention-deficit-hyperactivity disorder. Dev Med Child Neurol 2006;48:973-977.

52 Mautner VF, Kluwe L, Thakker SD, Leark RA: Treatment of ADHD in neurofibromatosis type 1. Dev Med Child Neurol 2002;44:164170.

53 Kayes LM, Burke W, Riccardi VM, Bennett R, Ehrlich P, Rubenstein A, Stephens K: Deletions spanning the neurofibromatosis 1 gene: identification and phenotype of five patients. Am J Hum Genet 1994;54:424-436.

54 Korf BR, Carrazana E, Holmes GL: Patterns of seizures observed in association with neurofibromatosis 1. Epilepsia 1993;34:616-620.

55 Daston MM, Scrable H, Nordlund M, Sturbaum AK, Nissen LM, Ratner N: The protein product of the neurofibromatosis type 1 gene is expressed at highest abundance in neurons, Schwann cells, and oligodendrocytes. Neuron 1992;8:415-428.

56 Ballester R, Marchuk D, Boguski M, Saulino A, Letcher R, Wigler M, Collins F: The NF1 locus encodes a protein functionally related to mammalian GAP and yeast IRA proteins. Cell 1990;63:851-859.

57 Bernards A: GAPs galore! A survey of putative Ras superfamily GTPase activating proteins in man and Drosophila. Biochim Biophys Acta 2003; 1603:47-82.

58 Costa RM, Federov NB, Kogan JH, Murphy GG, Stern J, Ohno M, Kucherlapati R, Jacks T, Silva AJ: Mechanism for the learning deficits in a mouse model of neurofibromatosis type 1. Nature 2002;415:526-530. 
-59 Nakazawa K, McHugh TJ, Wilson MA, Tonegawa S: NMDA receptors, place cells and hippocampal spatial memory. Nat Rev Neurosci 2004;5:361-372.

-60 Staley KJ, Anderson AE: Hyperactive interneurons impair learning in a neurofibromatosis model. Nat Neurosci 2009;12:8-10.

61 Cui Y, Costa RM, Murphy GG, Elgersma Y, Zhu Y, Gutmann DH, Parada LF, Mody I, Silva $A J$ : Neurofibromin regulation of ERK signaling modulates GABA release and learning. Cell 2008;135:549-560.

62 Shilyansky C, Karlsgodt KH, Cummings DM, Sidiropoulou K, Hardt M, James AS, Ehninger D, Bearden CE, Poirazi P, Jentsch JD, Cannon TD, Levine MS, Silva AJ: Neurofibromin regulates corticostriatal inhibitory networks during working memory performance. Proc Natl Acad Sci USA 2010;107:1314113146

63 Inoki K, Li Y, Zhu T, Wu J, Guan KL: TSC2 is phosphorylated and inhibited by Akt and suppresses mTOR signaling. Nat Cell Biol 2002;4:648-657.

64 Zhang Y, Gao X, Saucedo LJ, Ru B, Edgar BA, Pan D: Rheb is a direct target of the tuberous sclerosis tumor suppressor proteins. Nat Cell Biol 2003;5:578-581.

-65 Huang J, Manning BD: The TSC1-TSC2 complex: a molecular switchboard controlling cell growth. Biochem J 2008;412:179-190.

66 Laplante M, Sabatini DM: mTOR signaling in growth control and disease. Cell 2012;149: 274-293.
67 Wiznitzer M: Autism and tuberous sclerosis J Child Neurol 2004;19:675-679.

68 de Vries PJ, Watson P: Attention deficits in tuberous sclerosis complex (TSC): rethinking the pathways to the endstate. J Intellect Disabil Res 2008;52:348-357.

69 Ehninger D, Han S, Shilyanski C, Zhou Y, Li W, Kwiatkowski DJ, Ramesh V, Silva AJ: Reversal of learning deficits in a Tsc $2+/-$ mouse model of tuberous sclerosis. Nat Med 2008; 14 : 843-848.

$70 \mathrm{Fu}$ C, Cawthon B, Clinkscales W, Bruce A, Winzenburger P, Ess KC: GABAergic interneuron development and function is modulated by the Tsc1 gene. Cereb Cortex 2012;22: 2111-2119.

71 Meador KJ: The basic science of memory as it applies to epilepsy. Epilepsia 2007;48(suppl 9): 23-25.

-72 Bateup HS, Johnson CA, Denefrio CL, Saulnier JL, Kornacker K, Sabatini BL: Excitatory/ inhibitory synaptic imbalance leads to hippocampal hyperexcitability in mouse models of tuberous sclerosis. Neuron 2013;78:510-522.

73 Fatemi SH, Aldinger KA, Ashwood P, Bauman ML, Blaha CD, Blatt GJ, Chauhan A, Chauhan V, Dager SR, Dickson PE, Estes AM, Goldowitz D, Heck DH, Kemper TL, King $\mathrm{BH}$, Martin LA, Millen KJ, Mittleman G, Mosconi MW, Persico AM, Sweeney JA, Webb SJ, Welsh JP: Consensus paper: pathological role of the cerebellum in autism. Cerebellum 2012;11:777-807.
74 Tavano A, Grasso R, Gagliardi C, Triulzi F, Bresolin N, Fabbro F, Borgatti R: Disorders of cognitive and affective development in cerebellar malformations. Brain 2007;130:26462660.

75 Saab CY, Willis WD: The cerebellum: organization, functions and its role in nociception Brain Res Rev 2003;42:85-95.

76 Middleton FA, Strick PL: Cerebellar projections to the prefrontal cortex of the primate. J Neurosci 2001;21:700-712.

77 Hashimoto T, Tayama M, Murakawa K, Yoshimoto T, Miyazaki M, Harada M, Kuroda Y: Development of the brainstem and cerebellum in autistic patients. J Autism Dev Disord 1995;25:1-18.

78 Allen G, Courchesne E: Differential effects of developmental cerebellar abnormality on cognitive and motor functions in the cerebellum: an fMRI study of autism. Am J Psychiatry 2003;160:262-273.

79 Reith RM, McKenna J, Wu H, Hashmi SS, Cho SH, Dash PK, Gambello MJ: Loss of Tsc2 in Purkinje cells is associated with autisticlike behavior in a mouse model of tuberous sclerosis complex. Neurobiol Dis 2013;51:93103.

80 Tsai PT, Hull C, Chu Y, Greene-Colozzi E, Sadowski AR, Leech JM, Steinberg J, Crawley JN, Regehr WG, Sahin M: Autistic-like behavior and cerebellar dysfunction in Purkinje cell Tsc1 mutant mice. Nature 2012;488:647651. 